\title{
Physical properties of irrigated soils of Dev Bhumi Dwarka district of Gujarat
}

B. M. HADIYA AND J. V. POLARA

Received : 24.06.2017; Revised : 04.11.2017; Accepted : 14.11 .2017

\section{MEMBERS OF RESEARCH FORUM:}

Corresponding author :

J.V. POLARA, Department of Agricultural Chemistry and Soil

Science, Junagadh Agricultural

University, JUNAGADH

(GUJARAT) INDIA

Email: jvpolara@jau.in

Co-authors :

B.M. HADIYA, Department of Agricultural Chemistry and Soil Science, Junagadh Agricultural

University, JUNAGADH (GUJARAT) INDIA

Email: b.m.hadiya22@gmail.com

\section{Summary}

Thirty surface $(0-15 \mathrm{~cm})$ soil samples were collected from each talukas of Dev Bhumi Dwarka district viz., Kalyanpur, Dwarka, Khambhalia and Bhanvad. The physical characteristics of the soils were determined by using standard methods. The soils of Dev Bhumi Dwarka have overall values of bulk density, particle density, total porosity, MWHC and expansion varied from 1.21 to $1.57,2.20$ to $2.79 \mathrm{Mg} \mathrm{m}^{-3}, 34.82$ to $53.51,32.03$ to 55.34 and 6.52 to 22.65 per cent with mean value of $1.36,2.44 \mathrm{Mg} \mathrm{m}^{-3}, 44.09,43.76$ and 13.53 per cent, respectively.

Key words : Physical properties of soils, Bulk density, Particle density, Porosity, MWHC

How to cite this article : Hadiya, B.M. and Polara, J.V. (2017). Physical properties of irrigated soils of Dev Bhumi Dwarka district of Gujarat. Asian J. Soil Sci., 12 (2) : 254-256 : DOI : 10.15740/HAS/AJSS/ 12.2/254-256. 